\title{
TECHNICAL ALTERNATIVES ANALYSIS FOR WATER SUPPLY IN THE RURAL PARISH OF LIMONAL, ECUADOR
}

\author{
PAÚL CARRIÓN-MERO ${ }^{1,2}$, JOSUÉ BRIONES-BITAR ${ }^{1} \&$ EMILY MACÍAS-NÚÑEZ ${ }^{1}$ \\ ${ }^{1}$ Centro de Investigaciones y Proyectos Aplicados a las Ciencias de la Tierra (CIPAT), \\ ESPOL Polytechnic University, Ecuador \\ ${ }^{2}$ Facultad de Ingeniería en Ciencias de la Tierra (FICT), ESPOL Polytechnic University, Ecuador
}

\begin{abstract}
Drinking water (DW) provision in rural areas has always been a problem, either because of the quality requirements or the distribution requirements. The rural parish of Limonal in Ecuador and its surrounding areas have had difficulties in the DW provision. Nowadays, only the parish capital benefits from a DW treatment plant, but it has been small due to the accelerated population growth in recent years. In the present work, the aim is to analyze three alternatives of DW supply through its evaluation in a decision matrix for choosing the best alternative that covers the demand of DW in Limonal and that fulfills a good social acceptance. The methodology proposed in this study was as follows: (i) Technical-social information of the study sector, (ii) Data field collection, (iii) Interpretation of laboratory test results, (iv) Analysis and evaluation of the alternatives proposed by using the decision matrix, and (v) Election of the best alternative. The three alternatives proposed are: AP conduction from the cantonal head; groundwater supply; and rehabilitation and improvement of the treatment plant of the same parish. The alternative chosen was the third one, as it has a lower budget, it also has a better acceptance of the decision makers; and given the experience and practicality, it offered the best conditions in less time.
\end{abstract}

Keywords: drinking water, decision matrix, Ecuador, potabilization system, rural area, water supply.

\section{INTRODUCTION}

Water is an essential element for the sustainable development of a country as it plays an important role in economic, social and human development. Water scarcity currently, according to statistics from the United Nations Development Program, affects more than $40 \%$ of the world's population, and projected that this figure will continue to increase due to the increase in temperature by global warming [1].

Currently, we are going through the so-called global water crisis because only $3 \%$ of the total water resources in the world is fresh water. However, what seems to be a crisis is only a problem of governance and inadequate distribution of the resource; since, according to reports by the United Nations (UN) tell us that this amount is sufficient to cover the basic needs of all human beings [2].

In Latin America and the Caribbean, about $85 \%$ of the population has drinking water, either with free or easy access to a public source, suggesting a high level of coverage in this service. However, there is no equity in the access and use of these services and large disparities are observed between urban and rural areas [3].

In addition, it is common that technological solutions adapted in rural areas (such as wells and septic tanks) do not ensure a level of quality or functionality of services comparable to existing in cities (mainly household connections) [4].

DW provision in communities that are located in rural areas, has always been a problem mainly for the water quality that has been used. The Limonal parish and surrounding areas (San Lorenzo, Colorado, El Piñal, Valdivia, La Elvira and El Recreo) have had considerable difficulties for the provision and distribution of water for domestic use. 
Daule Public Water and Sewerage Company (EMAPA-EP) is responsible for providing to the citizens of the canton Daule with quality drinking water and sewerage services within current sanitary and environmental regulations, in accordance with good living, ensuring the reliability and operability of the systems, making them efficient, timely and accessible [5].

The inhabitants of the Limonal parish are supplied by a water treatment plant located in this rural parish, but it does not supply the entire population due to its lack of maintenance and the accelerated growth of the parish [6].

Therefore, in the present work, the aim is to analyze three alternatives of DW supply through its evaluation in a decision matrix for choosing the best alternative that covers the demand of DW in Limonal and that fulfills a good social acceptance. The present work intends, through technical requirements, to solve this serious problem in the rural parish Limonal and its surrounding.

\section{STUDY AREA}

Limonal, is one of the four rural parishes of the canton Daule (along with Laurel, Juan Bautista Aguirre and Los Lojas) (Fig. 1). It covers an area of $47.50 \mathrm{~km}^{2}$, and consists of six enclosures: San Lorenzo, Colorado, El Pinal, Valdivia, La Elvira and El Recreo.

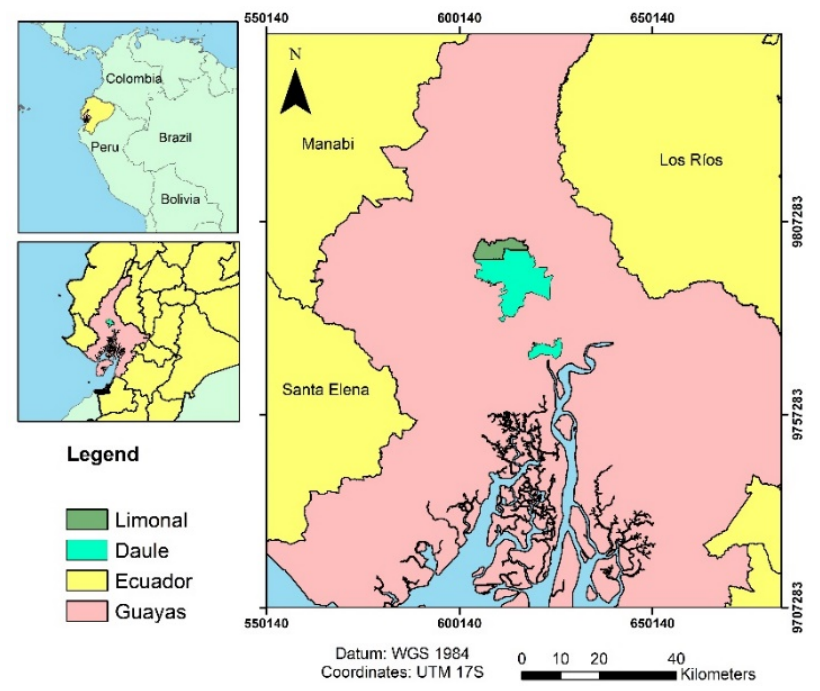

Figure 1: Location map of the Limonal and Daule parish. (Source: Modified from [7].)

According to [8], Limonal has a population of 8,774 inhabitants, of which most are engaged in agriculture, livestock and fishing. It has a dry tropical climate with an annual average temperature of $25^{\circ} \mathrm{C}$.

\subsection{Water supply in the Limonal parish}

The water supply in Limonal parish is very varied. According to [9], households are supplied with:

- Underground wells (45.34\%): It has three wells located in Piñal (enabled, but without maintenance; 30 years of operation), La Elvira and San Lorenzo (disabled). 
- Limonal treatment plant (31.18\%): water is taken directly from the Daule river, where it is then treated and then distributed.

- Others (23.48\%): through tank trucks and other treatment plants DW distribution.

That's why we will describe, briefly, the two main forms of water supply in Limonal.

\subsubsection{DW treatment plant in Limonal parish}

Limonal Parish DW treatment plant has nearly 15 years of operation on the banks of the Daule River. The operation of this plant is mostly with pressure; that is, by using pumps, but the last part that is the distribution, is by gravity (elevated tank). These processes are

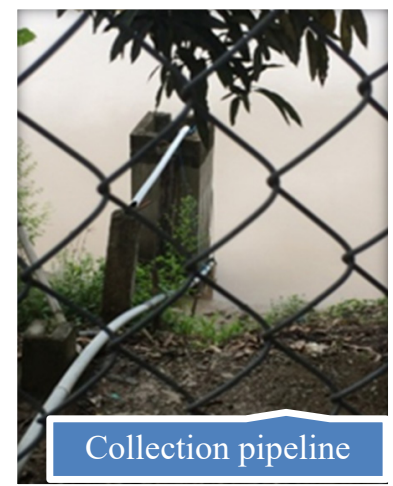

Collection pipeline
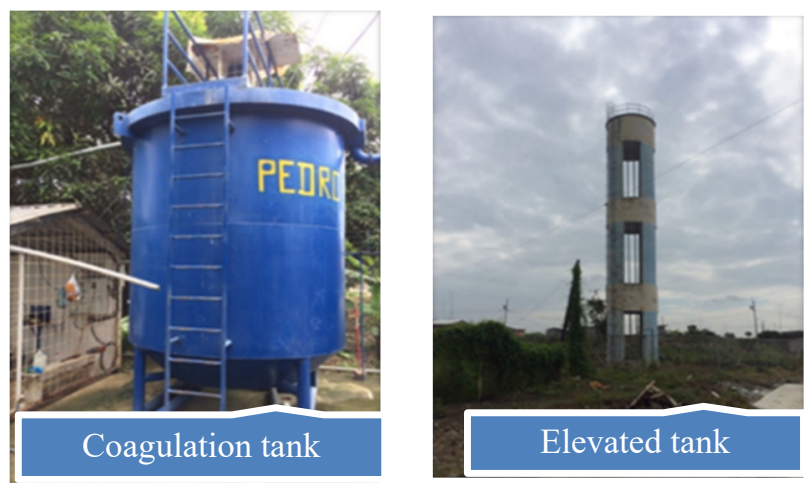

(a)

\section{DAULE RIVER}

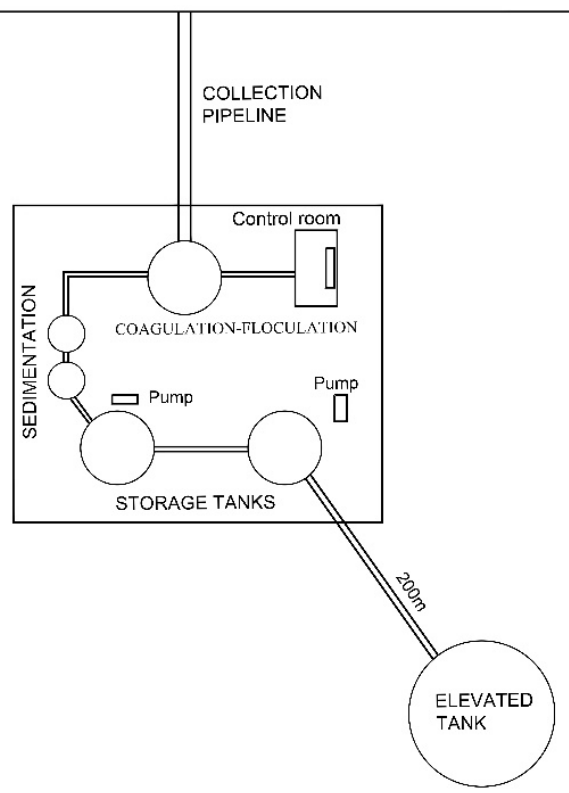

(b)

Figure 2: DW treatment plant in Limonal parish. (a) Plant processes; (b) Plan view. 
monitored by EMAPA-EP and every 15 days a company specialist comes to check if the chlorine and coagulant dosage is the indicated. This depends on the daily reports made by the EMAPA-EP laboratory that collected water and do physical and chemical tests. The process begins with the capture of water from the Daule River, to continue with the process of COAGULATION-FLOCULATION-SEDIMENTATION (all this carried out in the same tank). It continues the filtering process (consisting of two tanks containing layers of sand and gravel through which passes water), then follows the CHLORINATION (which is administered dropwise in the first storage tank) and finally the STORAGE (consists of two tanks, 10 and $15 \mathrm{~m}^{3}$ ). When the water is stored and allowed to stand for a while, it is taken by pumping to an elevated tank (this tower is located $200 \mathrm{~m}$ from the plant, with $20 \mathrm{~m}$ height) for distribution, by gravity, to households of the parish (Fig. 2).

\subsubsection{DW treatment plant in Daule parish}

This plant was built on 15 November 2011 to treat the water capture from Daule river and to solve the problem of water supply to the population in the parish. It has a treatment capacity of $400 \mathrm{~L} / \mathrm{s}$, it is a conventional hydraulic type; that is, it does not need pumps for the conduction of water from one process to another. The processes in this plant are: QUICK MIX, in this process a dose of chemical coagulant (aluminum sulfate type B liquid) is added, and thanks to the use of a Parshall gutter mixing occurs; FLOCULATION (slow mix), in this phase the water passes through a series of compartments in which the speed rate (from 90 to $60 \mathrm{~s}^{-1}$ ) is varied, this ensures the correct flocculation process; SEDIMENTATION, the water that enters the settler is almost at rest, this helps to better decanting suspended particles. With the help of pipelines located above the chamber, the water is transported to the next phase; FILTRATION, the filters are dual, that is, two filter materials that are sand and anthracite in different sizes for optimal operation; STORAGE 1, at this time chlorine is added, a portion to disinfect the water and another remains as residual chlorine; STORAGE 2 and DISTRIBUTION, with a drive line consisting of pumps, water is taken to a $300 \mathrm{~m}^{3}$ elevated tank capacity at $30 \mathrm{~m}$ height (Fig. 3).

\section{METHODOLOGY}

In Fig. 4, a summary scheme of the methodology followed in this work is presented, which consists of three phases.

\subsection{Phase I: Preliminary information}

In this phase, it collected all data related to socio-economic study of the sector. The review is carried out in scientific databases (articles, books, thesis) on the subject to be analyzed, with emphasis on those developed in the study sector. Moreover, as in the next phase will be analyzed alternatives for water supply, it is necessary to have information about national standards for the DW quality and distribution.

\subsection{Phase II: Technical analysis of the alternatives}

In this phase the collection of technical, social, environmental and economic data is carried out for the feasibility analysis of each alternative. The following describes the activities carried out:

- Water sampling and testing in laboratory conditions - water samples (physical, inorganic and bacteriological parameters) were taken and tested from the three main sources of 


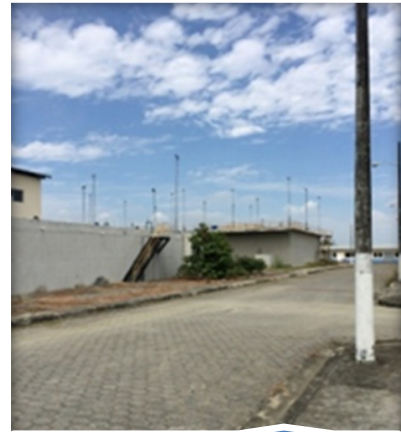

Chlorination (Storage 1)
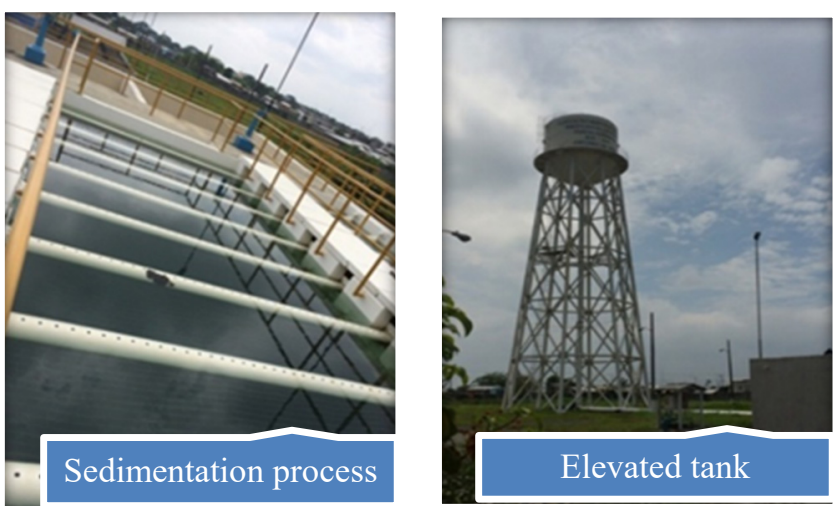

(a)

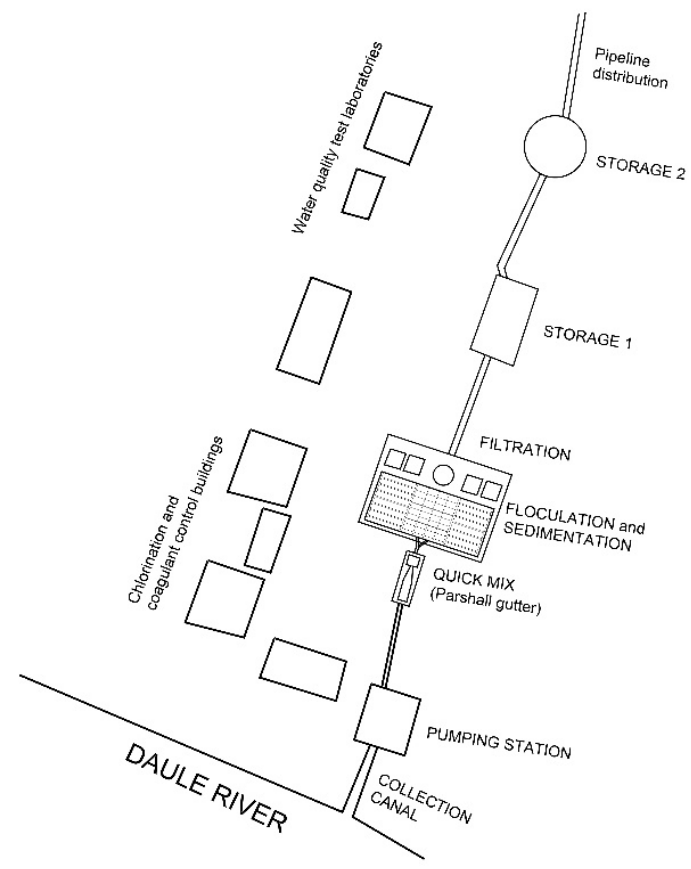

(b)

Figure 3: DW treatment plant in Daule parish. (a) Plant processes; (b) Plan view.

DW supply of the Limonal parish, such as DW treatment plant in Daule parish, in Limonal parish and in the well of Piñal. These spots were chosen because the alternatives considered were developed in these sectors.

- DW characterization - For this section, it is necessary to study national standards, such as the Ecuadorian Institute for Standardization (INEN for its acronym in Spanish 1108:2014 [10] and 1108:2006 [11]) and the Secondary Environmental Legislation Unified Text (TULAS for its acronym in Spanish) in its annex VI: Water quality [12]. 


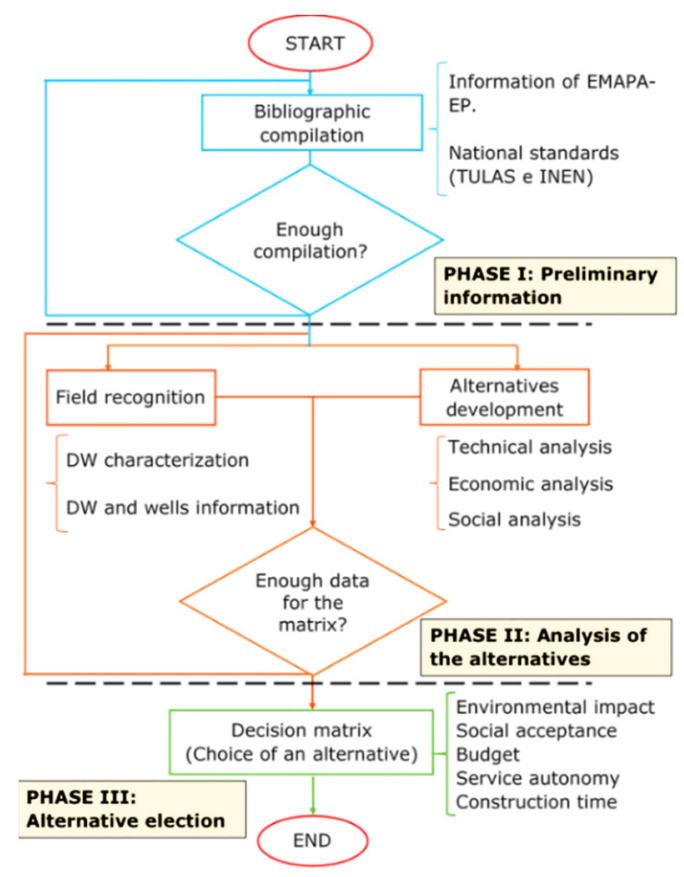

Figure 4: Methodology followed in this work.

- Future population and Endowment - According to the National Water Secretariat (SENAGUA) [13], to calculate future population is performed using at least three projection statistical methods. For this and thinking about the complexity of the problem, the best known were the Geometric, Wappaus and Exponential method. In eqns (1) and (3) you can see the formulas used by each projection method respectively. Obtained the three projections, an average was used

$$
\begin{gathered}
\mathrm{P}_{\mathrm{f}}=\mathrm{P}_{\mathrm{uc}} *(1+\mathrm{r})^{\mathrm{T}_{\mathrm{f}}-\mathrm{T}_{\mathrm{uc}}}, \\
\mathrm{P}_{\mathrm{f}}=\mathrm{P}_{\mathrm{ci}} * \frac{200+\mathrm{i} *\left(\mathrm{~T}_{\mathrm{f}}-\mathrm{T}_{\mathrm{ci}}\right)}{200-i *\left(\mathrm{~T}_{\mathrm{f}}-\mathrm{T}_{\mathrm{ci}}\right)}, \\
\mathrm{P}_{\mathrm{f}}=\mathrm{P}_{\mathrm{ci}} * e^{k *\left(\mathrm{~T}_{\mathrm{f}}-\mathrm{T}_{\mathrm{ci}}\right)},
\end{gathered}
$$

where:

$\mathrm{P}_{\mathrm{f}}=$ population corresponding to the year you want to project the population;

$\mathrm{P}_{\mathrm{uc}}=$ population corresponding to the last year census information;

$\mathrm{P}_{\mathrm{ci}}=$ population corresponding to the initial census with information;

$\mathrm{T}_{\mathrm{uc}}=$ year corresponding to the last census with information;

$\mathrm{T}_{\mathrm{ci}}=$ year corresponding to the initial census with information;

$\mathrm{T}_{\mathrm{f}}=$ year to which you want to project the information;

$\mathrm{r}, \mathrm{i}, \mathrm{k}=$ growth rate.

- $\quad$ Future water supply - eqn (4) given by SENAGUA was used.; since, is the maximum regulatory authority water in Ecuador

$$
\mathrm{D}=\frac{\mathrm{q} * \mathrm{~N}}{1000 * 86400}
$$


where:

$\mathrm{q}=$ provision for rural villages $(170 \mathrm{~L} / \mathrm{hab} / \mathrm{d})$;

$N=$ number of inhabitants.

With this information collected in the field and office, we proceeded to the approach and analysis of the three alternatives proposed. Three analyzes are performed: technical, social and economic; since these data are necessary for the choice of the best alternative.

\subsection{Phase III: Alternative election}

In this phase, the best alternative to be applied in Limonal is evaluated using a decision matrix. The indicators chosen and analyzed were: ENVIRONMENTAL (impacts caused by the proposed works), SOCIAL (the community acceptance), ECONOMIC (reference budget), AUTONOMY (independence of the proposal) and CONSTRUCTION TIME (time that the proposal would be operational).

Table 1 presents the weight was given to each indicator. This weight was considered based on two factors: i) criteria of experts on issues related to civil works; and ii) considerations made by the study beneficiaries, that is, the members of the Limonal Parish Board.

Table 1: Weighting given to each indicator.

\begin{tabular}{|l|c|}
\hline Indicator & Weight \\
\hline Environmental impact & 20 \\
\hline Social acceptance & 15 \\
\hline Economic & 20 \\
\hline Service autonomy & 30 \\
\hline Construction time & 15 \\
\hline
\end{tabular}

4 RESULTS

4.1 Water sampling and testing in laboratory conditions and DW characterization

In Table 2, the results of the physical-chemical analyzes performed are presented.

4.2 Technical analysis of the alternatives proposed

4.2.1 First alternative: DW provision from Daule parish treatment plant

The recommended time for the design of a water treatment plant, according to national standards, is 15 years. The results obtained are shown in Table 3.

Due to the large distances between Daule and Limonal (approximately $15 \mathrm{~km}$ to the furthest point) the following is proposed:

- The placement of a pumping station will be necessary due to the high pressure losses that will occur due to the large distances presented. The velocities in the distribution pipes, according to national standards, should be maintained between $0.6-2.5 \mathrm{~m} / \mathrm{s}$; that is why, according to the runs in specialized programs (such as EPANET) we propose to place a pressure pump to meet national standards.

- Valves will be added, at strategic points along the path, that allow independence and continuous operation in the event of damage or maintenance.

- $250 \mathrm{~mm}$ diameter pipes are proposed. 
Table 2: Results of the physical-chemical analyzes performed [14].

\begin{tabular}{|c|c|c|c|c|c|c|}
\hline \multirow[b]{2}{*}{ Parameter } & \multirow[b]{2}{*}{ Unit } & \multirow[b]{2}{*}{ Limonal } & \multirow[b]{2}{*}{ Daule } & \multirow[b]{2}{*}{ Piñal } & \multicolumn{2}{|c|}{ National quality standards } \\
\hline & & & & & $\begin{array}{c}\text { INEN } \\
\text { 1108:2014 }\end{array}$ & $\begin{array}{c}\text { TULAS } \\
\text { Annex VI }\end{array}$ \\
\hline \multicolumn{7}{|c|}{ Physical characteristics } \\
\hline Clarity & $\mathrm{Pt} / \mathrm{Co}$ & 85 & 7.64 & 39 & 15 & $20 * *-100 * * *$ \\
\hline Turbidity & NTU & 12.4 & 4.0 & 1.89 & 5 & $10 * *-100 * * *$ \\
\hline $\mathrm{pH}$ & & 7.25 & 4.2 & 7.34 & $6.5-8.5^{*}$ & $6.0-9.0 * *$ \\
\hline Total dissolved solids & $\mathrm{mg} / \mathrm{L}$ & 73.5 & 70 & 371 & $1,000^{*}$ & $500 * *-1,000 * * *$ \\
\hline Conductivity & $\mathrm{uS} / \mathrm{cm}$ & 154.3 & 145 & 761 & - & - \\
\hline Salinity & $0 / 00$ & $<0.1$ & $<0.1$ & 0.4 & - & - \\
\hline \multicolumn{7}{|c|}{ Inorganic } \\
\hline Alkalinity & $\mathrm{mg} / \mathrm{L}$ & 62 & 38 & 402 & - & - \\
\hline Barium $(\mathrm{Ba})$ & $\mathrm{mg} / \mathrm{L}$ & 0 & 0 & 0 & 0.7 & $1 * *$ \\
\hline Residual chlorine $\left(\mathrm{Cl}_{2}\right)$ & $\mathrm{mg} / \mathrm{L}$ & 0.8 & 0.71 & 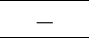 & $0.3-1.5$ & 1.5 \\
\hline Chlorides $(\mathrm{Cl})$ & $\mathrm{mg} / \mathrm{L}$ & 16.5 & 22 & 53.5 & $250^{*}$ & $250 * *$ \\
\hline Cobalt (Co) & $\mathrm{mg} / \mathrm{L}$ & 0.057 & 0.01 & 0 & $0.2 *$ & $0.2^{* *}$ \\
\hline Copper $(\mathrm{Cu})$ & $\mathrm{mg} / \mathrm{L}$ & 0.08 & 0.08 & 0.04 & 2 & $1 * *$ \\
\hline $\begin{array}{l}\text { Total hardness } \\
\left(\mathrm{CaCO}_{3}\right)\end{array}$ & $\mathrm{mg} / \mathrm{L}$ & 66 & 60 & 78 & $300^{*}$ & $500 * *$ \\
\hline Fluorine $(\mathrm{F})$ & $\mathrm{mg} / \mathrm{L}$ & 0.03 & - & 0.56 & 1.5 & $<1.4^{* *}-1.5^{* * *}$ \\
\hline Phosphorus $\left(\mathrm{PO}_{4}\right)$ & $\mathrm{mg} / \mathrm{L}$ & 1.79 & 0.46 & 4.38 & $0.1 *$ & - \\
\hline Total iron $(\mathrm{Fe})$ & $\mathrm{mg} / \mathrm{L}$ & 0.37 & 0.16 & 0.47 & $0.3^{*}$ & $0.3 * *-1 * * *$ \\
\hline Nickel (Ni) & $\mathrm{mg} / \mathrm{L}$ & 0.104 & 0.003 & 0.0 & 0.07 & $0.025 * *$ \\
\hline Nitrates $\left(\mathrm{NO}_{3}\right)$ & $\mathrm{mg} / \mathrm{L}$ & 1.3 & 0.5 & 0.7 & 50 & $10 * *$ \\
\hline Sulfates $\left(\mathrm{SO}_{4}\right)$ & $\mathrm{mg} / \mathrm{L}$ & 13 & 0.7 & 36 & $200^{*}$ & $250 * *-400 * * *$ \\
\hline \multicolumn{7}{|c|}{ Bacteriological } \\
\hline Fecal coliforms & UFC/100ml & $<1$ & $<1$ & $<1$ & $<1$ & $<1$ \\
\hline
\end{tabular}

* Limits taken from INEN 1108:2006.

Table 3: Population projection and required flow for water supply [14].

\begin{tabular}{|c|c|c|c|c|c|}
\hline \multirow{2}{*}{ Year } & \multicolumn{2}{|c|}{ Population projection } & \multicolumn{3}{c|}{ Flow (L/s) } \\
\cline { 2 - 6 } & Daule & Limonal & Daule & Limonal & Required \\
\hline 2017 & 122,383 & 8,058 & 240.8 & 16.1 & 256.9 \\
\hline 2018 & 126,342 & 8,179 & 248.6 & 16.3 & 264.9 \\
\hline 2019 & 130,429 & 8,302 & 256.6 & 16.6 & 273.2 \\
\hline 2020 & 134,650 & 8,426 & 264.9 & 16.8 & 281.7 \\
\hline 2021 & 139,010 & 8,552 & 273.5 & 17.1 & 290.6 \\
\hline 2022 & 143,514 & 8,681 & 282.4 & 17.3 & 299.7 \\
\hline 2023 & 148,169 & 8,811 & 291.5 & 17.6 & 309.1 \\
\hline 2024 & 152,979 & 8,943 & 301.0 & 17.9 & 318.9 \\
\hline 2025 & 157,952 & 9,077 & 310.8 & 18.1 & 328.9 \\
\hline 2026 & 163,094 & 9,213 & 320.9 & 18.4 & 339.3 \\
\hline 2027 & 168,412 & 9,352 & 331.4 & 18.7 & 350.1 \\
\hline 2028 & 173,914 & 9,492 & 342.2 & 19.0 & 361.2 \\
\hline 2029 & 179,607 & 9,634 & 353.4 & 19.2 & 372.6 \\
\hline 2030 & 185,499 & 9,779 & 365.0 & 19.5 & 384.5 \\
\hline 2031 & 191,600 & 9,925 & 377.0 & 19.8 & 396.8 \\
\hline 2032 & 197,919 & 10,073 & 389.4 & 20.1 & 409.4 \\
\hline
\end{tabular}


4.2.2 Second alternative: DW provision through use of groundwater

Limonal is located in the lower basin of the Guayas River, which has an area of 53,299 $\mathrm{km}^{2}$, being the largest hydrographic basin on the Pacific coast of South America. Also, land use in Limonal is mostly for agriculture, so the use of pesticides is constant. With this background, alternative 2 contemplates the use of groundwater by wells construction (Fig. 5).

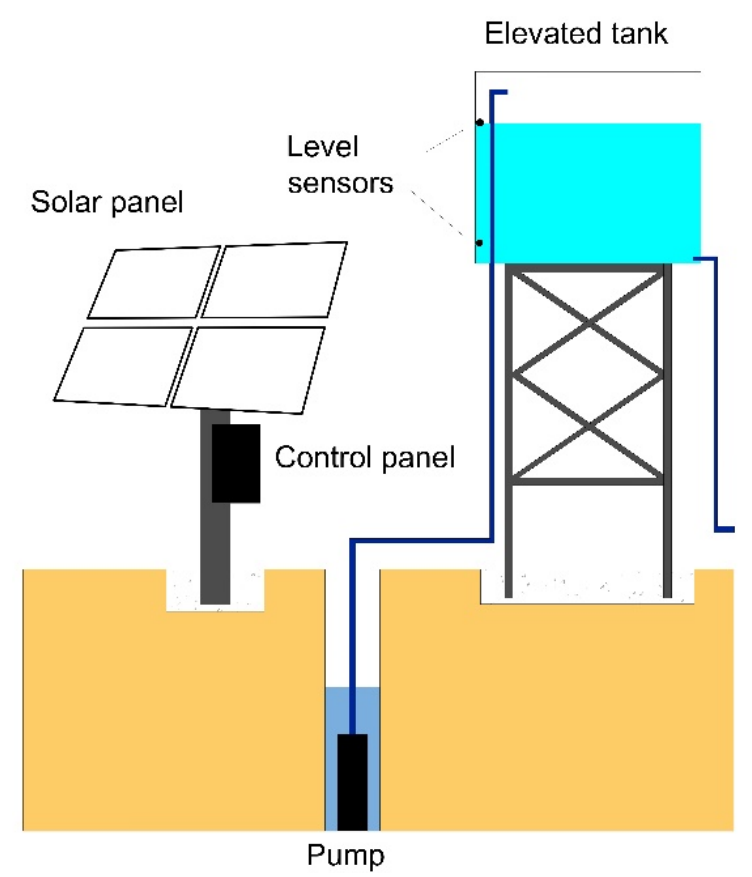

Figure 5: Alternative 2 illustration.

It is intended to place 6 tubular wells located strategically in the whole parish. The depth of these will be about $30 \mathrm{~m}$, this is proposed for greater uptake and effective protection against used pesticides. The use of submersible pumps to bring water to the surface is proposed.

An activated carbon filter will be placed on the surface for water treatment and for distribution, an elevated storage tank will be used.

The design will be completed with the use of solar panels as an alternative energy source, so that this alternative is autonomous and economical, in the long term.

\subsubsection{Third alternative: DW provision through rehabilitation of the water} treatment plant in Limonal parish

Based on Section 2.2, and, with the results of Tables 1 and 3, the rehabilitation and improvement of the processes of the Limonal treatment plant is proposed.

This rehabilitation is proposed for the next 15 years; so, it is necessary to increase the treatment capacity of this plant. It is contemplated performing a pipelines network for all precincts of the parish.

Due to the proximity of the precincts with the treatment plant, it is not necessary to use additional pumps during DW distribution. The use of valves, to make independent the distribution to each precinct, is contemplated. 
4.3 Social and economic analysis of the alternatives proposed

For the social analysis of the proposed alternatives, several meetings were held with the decision makers of the Limonal Parish and EMAPA-EP. For the Economic analysis, an estimated budget is presented, taking into account the Section 4.2.

A synthesis is presented in Table 4.

Table 4: Social and economic analysis of the alternatives proposed.

\begin{tabular}{|c|c|c|c|}
\hline & Alternative 1 & Alternative 2 & Alternative 3 \\
\hline Social & $\begin{array}{l}\text { It has a good acceptance, } \\
\text { because part of the } \\
\text { population of the parish is } \\
\text { supplied from the Daule } \\
\text { plant (Section 2.1). The } \\
\text { good relationship between } \\
\text { the mayor of Daule and the } \\
\text { president of the Limonal } \\
\text { Vestry is also highlighted. }\end{array}$ & $\begin{array}{l}\text { It has a fair } \\
\text { acceptance, because } \\
\text { the wells supply } \\
\text { almost half of the } \\
\text { population (Section } \\
\text { 2.1), but, due to use } \\
\text { and lack of } \\
\text { maintenance, it has } \\
\text { lost its quality. }\end{array}$ & $\begin{array}{l}\text { It has a good } \\
\text { acceptance, both of } \\
\text { the population and of } \\
\text { the decision makers. } \\
\text { The main problem } \\
\text { arises in rainy season, } \\
\text { causing increased } \\
\text { turbidity in Daule } \\
\text { river. }\end{array}$ \\
\hline Economic & USD $\$ 1,155,881.72$ & USD $\$ 908,657.19$ & USD $\$ 891,020.10$ \\
\hline
\end{tabular}

4.4 Choice of an alternative through the decision matrix

It is presented in Table 5, the decision matrix with the score assigned to each alternative. Table 5 was prepared and constructed according to three factors: (i) criteria of experts in the subject, (ii) evaluation by decision makers and (iii) the data and results presented in each alternative as described in Sections 4.2 and 4.3.

Table 5: Decision matrix with the assessment of each indicator for each alternative.

\begin{tabular}{|l|c|c|c|}
\hline Indicator & Alternative 1 & Alternative 2 & Alternative 3 \\
\hline Environmental impact (20) & 15 & 15 & 15 \\
\hline Social acceptance (15) & 12 & 10 & 12 \\
\hline Economic (20) & 10 & 15 & 15 \\
\hline Service autonomy (30) & 20 & 25 & 25 \\
\hline Construction time (15) & 15 & 15 & 15 \\
\hline Total & 72 & 80 & 82 \\
\hline
\end{tabular}

\section{ANALYSIS OF RESULTS}

All the alternatives proposed are viable in this sector of study, but in the evaluation process of each one, the following restrictions were taken into account:

- Distribution distance, due to pressure losses and the cost involved.

- Possible contamination in aquifers due to pesticide use in agriculture.

- In the study sector, the houses are very far from each other.

- Existence of high turbidity in the river flows in a high percentage of the year.

- The level of autonomy of each alternative, considering low river flow, loss of electricity or high service maintenance costs. 
Due to these previous criteria, Table 1 was formulated, giving higher weights to certain indicators considered more relevant than others; as they are, the economic, service autonomy and environmental impact.

According to Table 5, in each alternative, it is defined that alternatives 2 and 3 are the most indicated to solve the DW supply problem in the parish. This is because the score is almost similar, it only differs by the social indicator (due to the possible presence of pesticides).

According to the results in Table 2, in all water supply sources it is necessary to apply some corrective measures, referring to water quality processes. The parameters, in which the national quality standards are not met, are color, turbidity, phosphorus, iron and nickel. Alternative 1 presents fewer quality problems, this because the plant was just opened in 2011; meanwhile, the Limonal plant has been operating since 2003 and El Piñal well since 1989.

Alternative 2 is presented as a potential option, but a more in-depth study is recommended (to increase its social acceptance); since, if this, alternative 2 could work and be sustainable as proposed in Manglaralto by [15], [16], which supplies water to about 30,000 inhabitants.

Alternative 1, can guarantee water quality throughout the year, but the non-choice of this alternative is given by three aspects: (i) water supply is conditioned to the operation of the plant, (ii) Table 3 shows the required flow, but in 2032, exceeds the capacity of the plant ( $400 \mathrm{~L} / \mathrm{s})$, so it would not meet national quality standards; and, (iii) according to Table 4, this alternative is the most expensive, considering that it is a rural parish, it would not have enough funds to cover it.

\section{CONCLUSIONS}

In this study three alternatives were presented, which were analyzed from three perspectives: technical, economic and social. In addition to this, for the election of one, were evaluated in a decision matrix with different indicators and weights (Autonomy 30\%, Environmental Impact 20\%, Economic 20\%, Social Acceptance 15\% and Construction Time 15\%), according to criteria of experts and decision makers.

The alternative selected was the third one, which includes the improvement and repowering of the Limonal treatment plant in the study sector, with a lower budget $(\$ 891,020.10)$ and a good social acceptance.

The constant monitoring of the water quality is necessary, since, due to the change of seasons, the river water increased turbidity, so the necessary adjustments in the treatment processes must be adopted to ensure its quality.

Alternative 3 does not meet certain parameters (turbidity, clarity, phosphorus and total iron); what causes discomfort and doubt, about the quality of this, among the inhabitants.

Alternative 2 is emerging as a potential and attractive long-term alternative, but a more in-depth study is necessary, to know if underground sources of supply are or have potential for contamination due to pesticides.

\section{ACKNOWLEDGEMENTS}

To members of the Limonal parish board for the help provided during this study especially to its president, Ing. Xavier Solano. To the experts who helped us: Ing. Miguel Ángel Chávez, $\mathrm{Ph}$. D, Ing. Otto Córdova and Ing. Jaime Páez. To ESPOL Link Unit project (UVS, its acronym in Spanish) in the Limonal parish. 


\section{REFERENCES}

[1] Informe de las Naciones Unidas sobre los recursos hídricos en el mundo 2015, WWDR (PNUD los Recursos Hídricos en el Mundo). www.unesco.org/new/fileadmin/ MULTIMEDIA/HQ/SC/images/WWDR2015Facts_Figures_SPA_web.pdf. Accessed on: 16 May 2019. (In Spanish.)

[2] El acceso al agua potable, ¿un derecho humano? Centro Nacional de Derechos Humanos de la CNDH, Luisa Fernanda Tello Moreno. www.senado.gob.mx/ comisiones/recursos_hidraulicos/docs/doc13.pdf. Accessed on: 16 May 2019. (In Spanish.)

[3] Evaluación de la condición del agua para consumo humano en Latinoamérica, Centro de Estudios Transdisciplinarios del Agua, Universidad de Buenos Aires, Alicia Fernández Cirelli y Cecile du Mortier. https://s3.amazonaws.com/academia.edu. documents/31367666/01_Capitulo_01.pdf?AWSAccessKeyId=AKIAIWOWYYGZ2 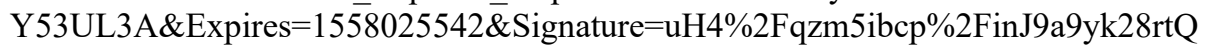 g\%3D\&response-content-disposition=inline\%3B\%20filename\%3D01_Capitulo_ 01.pdf. Accessed on: 16 May 2019. (In Spanish.)

[4] Jouravlev, A., Los servicios de agua potable y saneamiento en el umbral del siglo XXI. Serie Recursos Naturales e Infraestructura, 74(1), 70 pp., 2004. (In Spanish.)

[5] Misión/Visión, Empresa Pública de Agua Potable y Alcantarillado de Daule. www.emapadaule.gob.ec/mision/vision. Accessed on: 16 May 2019. (In Spanish.)

[6] Limonal espera ejecución del alcantarillado, Diario El Universo, Noticia del 16 de febrero del 2015. www.eluniverso.com/noticias/2015/02/16/nota/4561296/limonalespera-ejecucion-alcantarillado. Accessed on: 16 May 2019. (In Spanish.)

[7] Limonal espera ejecución del alcantarillado; Diario El Universo, Noticia del 16 de febrero del 2015. www.eluniverso.com/noticias/2015/02/16/nota/4561296/limonalespera-ejecucion-alcantarillado. Accessed on: 16 May 2019. (In Spanish.)

[8] Archivos de Información Geográfica, Sistema Nacional de Información (SNI). https://sni.gob.ec/coberturas. Accessed on: 10 Jan. 2020.

[9] Generalidades, Gobierno Autónomo Descentralizado Ilustre Municipalidad de Daule (GAD Daule). www.daule.gob.ec/es-ec/nuestrocantón/generalidades.aspx. Accessed on: 16 May 2019. (In Spanish.)

[10] Instituto Ecuatoriano de Normalización (INEN), INEN 1108:2014. www.pudeleco.com/files/a16057d.pdf. Accessed on: 11 Jan. 2020. (In Spanish.)

[11] Instituto Ecuatoriano de Normalización (INEN), INEN 1108:2006. www.dspace.espol.edu.ec/bitstream/123456789/10608/8/Norma\%20Inen\%20Agua1 108-2.pdf. Accessed on: 11 Jan. 2020. (In Spanish.)

[12] Texto Unificado de Legislación Secundaria de Medio Ambiente (TULSMA), Anexo VI: Calidad de las aguas. www.dspace.espol.edu.ec/bitstream/123456789/6078/36/ LIBRO\%20VI\%20Anexo\%201\%20Normas\%20Recurso\%20Agua.pdf. Accessed on: 11 Jan. 2020. (In Spanish.)

[13] Secretaría Nacional del Agua (SENAGUA), Norma de diseño para sistemas de abastecimiento de agua potable, disposición de excretas y residuos líquidos en el área rural. www.agua.gob.ec/wp-content/uploads/downloads/2014/04/norma_rural_para_ estudios_y_disenos.pdf. Accessed on: 11 Jan. 2020. (In Spanish.)

[14] Briones, J. \& Macías, E., Estudios y diseños del sistema de potabilización del agua de la parroquia del Limonal, cantón Daule, provincia del Guayas, Tesis de grado/ Escuela Superior Politécnica del Litoral (ESPOL). www.dspace.espol.edu.ec/xmlui/handle/ 123456789/42627. Accessed on: 17 May 2019. (In Spanish.) 
[15] Carrión, P., Herrera, G., Briones, J., Sánchez, C. \& Limón, J., Practical adaptations of ancestral knowledge for groundwater artificial recharge management of Manglaralto coastal aquifer, Ecuador. WIT Transactions on Ecology and the Environment, vol. 217, WIT Press: Southampton and Boston, pp. 375-386, 2018.

[16] Herrera, G., Carrión, P. \& Briones, J., Management practices for a sustainable community and its impact on development, Manglaralto-Santa Elena, Ecuador. Proceedings of the LACCEI International Multi-Conference for Engineering, Education and Technology, 2019. 